\title{
PERILAKU HOMOSEKSUAL DALAM PANDANGAN HUKUM ISLAM
}

\author{
Latief Mahmud
}

(Jurusan Syari'ah STAIN Pamekasan dan Alumni S2 Unmuh Malang)

\begin{abstract}
Abstrak
Penyaluran syahwat diatur secara gamblang oleh al-Quran yaitu dengan melalui jalur pernikahan. Dan pernikahan harus dilakukan antara dua jenis kelamin yang berbeda, laki-laki dengan perempuan. Karena itu, penyaluran syahwat antar sesama jenis seperti yang digambarkan dalam al-Qur'ân sebagaimana perilaku kaum Nabi Luth sangat dikutuk dan dilarang oleh al-Qur'ân. Namun demikian, masih banyak yang memanfaatkan cara tersebut (homoseksual), baik antar sesama laki-laki disebut kaum gay maupun antar sesama perempuan disebut kaum lesbiyan. Tulisan ini mengelaborasi secara detail pandangan hukum Islam tentang homoseksual baik dilihat dari aspek hukumnya maupun bentuk hukumannya.
\end{abstract}

\section{Kata Kunci:}

homoseksual, lesbian, gay, biseksual, dan hukum Islam

\section{Pendahuluan}

Kaum homoseksualitas ${ }^{1}$ nampak sedang mencari jati diri, penampilan mereka cenderung destruktif dan bersifat negatif sehingga orang sekitarnya memandang mereka sebagai orang-orang yang sedang sinting dan kesepian diatas bumi ini. Pada era tahun 1970an keadaan itu berubah dengan cepat, penikmat homoseksualitas semakin bertambah dan bahkan mulai percaya diri, keberanian mereka semakin bertambah yang tadinya mereka sembunyisembunyi atau tertutup untuk menyatakan diri sebagai mana layaknya seorang hetroseksual.

Pada era modern ini ternyata semakin banyak penyimpangan perilaku seksual, dimana nilai-nilai moral, etika agama sudah

\footnotetext{
${ }^{1}$ Homoseksualitas ialah relasi seks dengan jenis kelamin yang sama
} 
diabaikan bahkan masyarakat cenderung menerima perilaku homoseksulitas ini. Ada kecenderungan di antara masyarakat dewasa ini menerima perilaku homoseksual atas nama hak asasi manusia, keadilan dan toleransi. Tapi di sisi lain tidak sedikit di kalangan masyarakat menuntuk agar diberi hukuman tegas terhadap pelaku homoseksualitas itu, terutama kaum muslimin karena perilaku homoseksualitas tersebut dianggap bertentangan dengan nilai-nilai dasar Islam.

Homoseksualitas bukanlah merupakan suatu periku yang baru, ia telah lama ada ditengah-tengan masyarakat tetapi kuantitasnya berbeda dengan pada zaman modern ini. Pada masyarakat dahulu tentu perilaku homoseksualitas ini lebih sedikit dan dilakukan dalam kerahasiaan dan bahkan tertutup.

\section{Homoseksual : Kaum Gay dan Lesbian}

Kaum homoseksual terdiri dari kaum gay dan kaum lesbian ${ }^{2}$ sebagaimana mereka menyebut nama mereka sendiri, saat ini di Amerika Serikat berusaha dengan sekuat tenaga untuk diakui keberadaanya sebagai suatu komonitas atau kelompok masyarakat melalui lobi-lobi sosial politik dan bahkan kepada Clinton mantan kepala negara Amerika Serikat untuk mendapatkan pengakuan publik. ${ }^{3}$ Yang sebenarnya mayoritas masyarakat Amerikat Serikat itu beranggapan bahwa homoseksual itu merupakan perilaku yang salah dan menyimpang tetapi secara tidak terduga usaha mereka mendapat pengakuan publik bahkan menjadi gaya hidup alternatif, kecenderungan personal sebuah variasi hidup alami di Barat.

Program pokok kaum homoseksual yaitu berusaha dengan segala kemampuan yang dimiliki agar dapat diterima dan diakui oleh masyarakat sebagai suatu komunitas dan berusaha merekrut anggota baru. Aktivitas sosial mereka adalah memberi bantuan kepada masyarakat yang membutuhkan serta propaganda bahwa mereka adalah korban diskriminasi gender, karena itu mereka mendukung terciptanya suatu undang-undang anti diskriminasi gender yang melegalkan perkawinan sesama jenis. Mereka membiayai riset

${ }^{2}$ Gay ialah laki-laki yang homoseksual sedang perempuan yang homoseksual disebut lesbian

3 Abu Ameenah Phillips dan Zafar Khan, Islam dan Homoseksual (Jakarta: Pustaka Zahra, 2000), hlm. 3 


\section{Latief Mahmud}

tentang isu hypothalamus ${ }^{4}$. Perkawinan dua orang laki-laki atau dua orang perempuan untuk membangun sebuah mahligai keluarga yang setara dengan keluarga tradisonal

Kaum homoseksual di Amerika serikat memprotes gerejagereja, masjid-masjid yang berani menyuarakan bahwa kaum homoseksual adalah perilaku yang menyimpang dan salah secara moral karena itu tidak seorang politikuspun yang mau dicap sebagai seorang homophobic ${ }^{5}$ setelah Asosiasi Psikiater Amerika (American Psychiatric Assciation) pada tahun 1976 mengatakan bahwa kaum homoseksual itu tidak lagi dianggap sebagai suatu penyakit ${ }^{6}$

Kaum homoseksual ini banyak dipersalahkan karena banyaknya penularan penyakit AIDS di Barat seperti Amerika Serikat, Inggris, Belanda melalui tranfusi darah tetapi perilaku kaum homoseksual ini dibiarkan oleh para politisi atas nama keadilan.

Gerakan kaum homoseks ini memiliki jaringan kelompok pendukung yang kuat dan mereka mempromosikan perilaku ini, menyuburkan konflik dalam keluarga dan masyarakat. Mereka memakai alat media televisi untuk mempromosikan kelompoknya. Kaum homoseks Amerika kini memiliki hajatan tahunan yang biasa disebut Gay Pride Parade (Parade Bangga Menjadi Gay)

Bagi masyarakat Indonesia kaum homoseksualitas dianggap sebagai suatu makhluk yang aneh walaupun mereka jumlahnya banyak, tapi mereka tertutup karena diawasi oleh budaya dan agama yang ketat, pada kenyataannya orang-orang yang kecenderungan orientasi seksualnya menyimpang ini ada dalam kehidupan bahkan mungkin ada disekitar kita. Manusia normal memiliki orientasi seksual pada lawan jenisnya, seorang pria tertarik pada wanita dan sebaliknya seorang wanita tertarik pada seorang pria mereka ini disebut sebagai kaum heteroseksual?

\footnotetext{
4 Hypothalamus yaitu berusaha menunjukkan bahwa homoseksual merupakan kecenderungan genetik

5 Homopobic ialah merasakan ketakutan yang irrasional (rakyat Amerika) terhadap kaum homoseksualitas serta takut membenci dan mendiskriminasi terhadap kaum homoseksualitas.

${ }^{6}$ Philips dan Khan, Islam, hlm.4

7 Heteroseksual ialah seseorang tertarik kepada lain jenisnya seperti seorang laki-laki tertarik kepada seorang perempuan dan sebaliknya seorang perempuan tertarik pada seorang laki-laki
} 
Seorang homoseks tidak memiliki kecenderungan seksual yang normal justru mereka lebih tertarik kepada sesama jenisnya. Pria yang tertarik pada sesama jenisnya biasa disebut dengan istilah gay dan bagi perempuan yang tertarik pada sesama jenisnya biasa disebut dengan istilah lesbian.

Orang-orang yang mengalami kekacauan orientasi seksualnya mereka memandang laki-laki dan perempuan sama saja, orang seperti ini bisasa disebut dengan istilah biseksual ${ }^{8}$ Fenomena biseksual ini biasa terjadi akibat eksplorasi seksual yang dilakukan kaum muda, hal itu terjadi karena kaum muda memiliki kecenderungan bersifat labil dan keingintahuan yang besar. Mereka mempraktekkan perilaku biseksual ini hanya karena penasaran dan ingin mencobacoba. Dari mencoba-coba ini ada di antara mereka menjadi kebiasaan yang menyenangkan dan ada pula yang tidak meneruskan perbuatan nyeleneh itu.

Homoseksual menimbulkan banyak masalah dan menjadi perhatian serius berbagai kalangan pemerhati sosial, biologi, kesehatan, agama dan lain-lain. Ketenaran homoseksual di dunia Barat atas pengakuan Dean Hamer seorang peneliti dari National Cancer Institute tahun 1993 bahwa ia telah menemukan bukti konkrit bahwa "gen" gay benar-benar ada dan orientasi homoseksual kemungkinan kelaki-laki melalui kromoson $X$ dari sang ibu. Kemudian penemuan ini dipublikasikan dalam jurnal ilmiyah terkemuka sehingga nama Hamer menjadi populer. Penemuan Hamer dibantah oleh parah peneliti lainnya dari University of Western Ontario yang gagal menemukan hubungan apapun dengan kromoson $X$ dengan orientasi seksual. Dalam hal ini Hamer sebenarnya berbohong dalam penelitiannya karena ia sendiri adalah seorang gay. ${ }^{9}$

AIDS membuktikan bahwa perilaku homoseksual adalah lebih banyak menularkan penyakit tersebut dan telah membunuh beriburibu manusia dengan kejam. Penyakit AIDS sampai kini belum ditemukan obatnya. Termasuk penyakit kelamin lainnya seperti penyakit gonore (kencing nanah), sifilis (raja singa) yang sangat

\footnotetext{
${ }^{8}$ Biseksual yaitu orang-orang yang mengalami kekacauan seksual memandang lakilaki dan perempuan sama saja

9 Philips dan Khan, Islam, hlm.21
} 


\section{Latief Mahmud}

ditakuti, penuran penyakit ini $80 \%$ oleh para homoseksual. WHO melaporkan pada tahun 2000 yang lalu bahwa penyakit AIDS di Belanda menghinggapi kaum homoseksual 68,6\%, di Inggris 65,8\%.10 Demikian juga hasil penelitian psikiater tahun 1999 yang mengatakan bahwa yang paling banyak kecenderungan bunuh diri dan ide bunuh diri adalah kaum homoseksual dibandingan dengan kaum heteroseksual yaitu 6,5 berbanding 1 .

Melihat sejarah keberadaan kaum homoseksual ini hampir tidak pernah sepi dari lingkungan kehidupan umat manusia namun setiap masa berbeda dalam gaya penampilannya, mulai dari jaman Nabi Luth a.s hingga jaman modern ini, mulai dari desa sampai kota selalu ada kaum homoseksual ini. Kalau di kampung atau desa mungkin mereka masih malu-malu dan risih tampil secara terangterangan tetapi di kota-kota besar malah sebaliknya mereka mendirikan asosiasi dan minta diakui eksistensinya. Di Surabaya misalnya kita akan temui di mal-mal, plaza-plaza, di jalan-jalan protokol, di dalam bus kota setiap malam.

Melihat dari keberadaan mereka tidak mungkin ditolak dan dihujat serta diasingkan tetapi perilaku seksual itu yang perlu mendapat pengawasan yang ketat sehubungan mudharat yang ditimbulkannya berdasarkan keterangan dari para dokter, psikolog, psikiater, sosiolog dan agamawan. Homoseksualitas sebenarnya adalah suatu penyakit yang perlu disembuhkan. Terapinya adalah akal yang sehat, moral dan agama.

\section{Macam-Macam Penyimpangan Seksual}

\section{Heteroseksual}

Penyimpangan seksualitas disebabkan oleh dorongan seksual yang tidak normal ini, ragamnya banyak, di antaranya prostitusi (pelacuran), promiscuity (hubungan seksual dengan bebas), adultery (perzinahan), seduksi (perkosaan).

Penyimpangan seksual berupa pelacuran dengan dorongan seksual yang tidak wajar, dorongan seksual yang tidak terintegrasi dalam kepribadian sehingga relasi seksual ini sifatnya impersonal, tanpa efeksi dan emosi (kasih sayang), berlangsung cepat tanpa

\footnotetext{
${ }^{10} \mathrm{Ibid}, \mathrm{hlm} 24$
} 
mendapatkan orgasme dari pihak wanita. Seks semacam ini dijadikan sebagai barang dagangan sehingga terjadi komersialisasi seks berupa pertukaran kenikmatan dengan materi atau uang. Pelacur wanita disebut Wanita Tuna Susila (WTS), sedang pelacur laki-laki disebut gigolo (PTS). Menurut Kartini Kartono ${ }^{11}$ bahwa pelacur termasuk didalamnya; pergundikan, tante girang, gold digger (penggali mas), taxi girl (gadis taksi), call girl (gadis panggilan), bar gir (gadis bar), hostess (pramuria), free girl (gadis binal).

Ada beberapa penyebab sehingga kaum lelaki melakukan relasi seksual atau pelacuran di antaranya; mencari variasi relasi seksual, atau ingin mencari sensasi (iseng), istri sedang hamil, jauh dari istri karena sedang tugas. Sedangkan bagi wanita terdorong untuk melakukan prostitusi karena didorong oleh nafsu yang abnormal, karena didorong oleh kebutuhan materi dan mudah mendapatkannya dengan cara bermalas-malasan, membenrontak terhadap otoriter orang tua, karena kehidupan kedua orang tuanya tidak harmonis (broken home), kompensasi terhadap rasa rendah diri, adanya keinginan hidup ekonomi standar tinggi, karena kecanduan obat-obat terlarang seperti ganja, obat bius, minuman keras karena itu harus menjual diri untuk mendapatkan uang.

Ada beragam reaksi masyarakat terhadap pelacuran ini di antaranya; ada yang menyetujui adanya, adapula yang sangat menentang dan ada yang netral. Yang menyetujui tentang keberadaan pelacuran itu karena pelacuran keberadaannya seumur dengan sejarah keberadaan manusia itu sendiri dan tidak mungkin dihapuskan selama manusia masih ada. Sedangkan masyarakat yang menentang beralasan bahwa mereka bertingkah laku amoral yang mencolok, berpengaruh terhadap lingkungan sosialnya, menjadi sumber penularan penyakit seperti penyakit syphilis, AIDS dan lainlain. Dan mereka yang bersifat netral berpendapat bahwa karena pelacuran itu keberadaannya seumur dengan sejarah kehidupan manusia maka sulit untuk dihapuskan tetapi keberadaan mereka sangat mengganggu lingkungan sosial lainnya maka sebagai solusinya yang terbaik adalah merelokasi mereka ke tempat yang jauh dari lingkungan kehidupan masyarakat yang normal.

11 Kartini Kartono, Psikologi Abnormal danAbnormalitas Seksual (Bandung: Mandar Maju, 1989), hlm., 233 


\section{Latief Mahmud}

Hubungan seksual secara bebas dengan banyak orang yang biasa disebut dengan promiscuity merupakan tindakan seksual yang immoril, terang-terangan tanpa malu sebab didororong oleh nafsu seksual yang tidak matang dan tidak wajar. Tindakan promiscuity tidak jauh beda dengan prostitusi hanya saja promiscuity tidak menuntut imbalan materi tetapi mereka menuntut kebebasan seksual dengan siapa saja. Mereka tidak mau dibatasi dengan aturan-aturan, norma-norma sosial dan agama. Pelaku wanita disebut sebagai amatrice sedang pelaku peria dinamakan amateur atau biasa disebu dengan istilah Don Juan. Menurut para ahli psikologi seksual bahwa mereka ini tidak mendapatkan kenikamatan dalam seksual tetapi justru mengakibatkan mental meraka labil, tidak bertanggung jawab dan bertentangan dengan prinsip-prinsip kedewasaan. Kehidupan seks bebas ini banyak melanda pada masyarakat maju dan berkecukupan. Adultery (perselingkuhan) merupakan relasi seksual antara seorang laki-laki yang sudah kawin dengan seorang perempuan yang bukan partner legalnya (istri) baik perempuan itu istri orang lain, janda atau gadis). Perizahan seperti ini banyak terjadi pada zaman modern ini tetapi secara sembunyi-sembunyi. Di negaranegara yang menganut faham kebebasan jaustru kebebasan seksual ini biasanya banyak dianut oleh masyarakat yang ingin mendapatkan variasi seksual, biasanya pihak suami mengijinkan istrinya melakukan perzinahan sebagai tambahan kepuasan seksual. Ijin perzinahan istrinya itu diberiakan untuk dijadikan sebagai alasan baginya dalam melakukan perzinahan (perselingkuhan) dengan perempuan lainnya. Pada umumnya perselingkuhan ini banyak menimbulkan kesengsaraan dan penderitaan bahkan perceraian dengan istrinya.

Perkosaan atau biasa juga disebut dengan seduksi karena biasanya membujuk seorang perempuan untuk melakukan relasi seksual dengan cara paksa. Bujukan itu bisanya bersifat janji akan dikawini dan kehidupannya akan ditanggung. Dalam seduksi ini mengandung bujukan dan tekanan tertentu agar siwanita mau melakukan relasi seksual. Bujukan dan tekanan itu bersifat paksaan. Tetapi istilah perkosaan itu sendiri mengandung pengertian kasar yaitu melakukan relasi seksual dengan cari paksa dengan seorang wanita. Perkosaan merupakan perbuatan kriminal yang dikecam oleh masyarakat dengan ancaman hukuman yang berat. Perkosaan itu 
didorong oleh nafsu seksual yang kuat dan abnormal dan biasanya dibarengi tindakan kekerasan.

\section{Penyimpangan seksual dengan cara pemuasan seks tidak wajar}

Termasuk penyimpangan seksual ini ialah onani (masturbasi), sadisme dan masokhisme, ekshibionisme seksual, transvestitisme. Dari sekian banyak pemuasan seksual yang tdak wajar melalui caracara tersebut perlu kiranya diberi penjelasan untuk mengetahui sebab dan akibatnya.

Onani atau masturbasi yaitu suatu upaya untuk mencapai satu keadaan ereksi organ-organ kelamin untuk mencapai orgasme melalui ransangan manual seperti tangan atau rangsangan secara mekanik. Onani atau masturbasi ini merupakan suatu aktivitas penodaan diri sendiri dengan penyalah gunaan seksual dalam bentuk merangsang alat kelaminnya sendiri baik secara manual atau secara digital. ${ }^{12}$

Onani pada masa kanak-kanak dan orang dewasa merupakan gejala yang abnormal namun onani pada masa remaja (pubertas) banyak terjadi, hal ini disebabkan oleh kematangan seksual mereka sedang memuncak dan tidak mendapatkan penyaluran yang wajar apalagi ditambah dengan rangsangan berupa buku-buku dan gambar-gambar porno serta blue film. Menurut pada ahli psikologi seksual bahwa anak-anak yang puber yang melakukan onani jumlahnya mencapai 70\%-90\% sehingga gelaja yang melakukan onani pada masa ini merupakan hal yang umum ${ }^{13}$ sebab onani merupakan jalan pemuasan seksual yang alami berdasarkan pertimbangan psikologis, biologis, sosial dan moril karena tidak bisa dipuaskan secara wajar melalui coitus.

Onani pada remaja putri tidaklah sehebat dengan remaja putra karena remaja putri dorongan seksualnya bisa disalurkan melalui psikis dalam bentuk fantasi, kegelisahan, konflik batin, mimpi dan sebagainya. Karena itulah onani pada masa remaja bukanlah dianggap sebagai penyakit, tetapi masturbasi di kalangan kanakkanak dan orang dewasa dianggab sebagai gejala abnormal karena

\footnotetext{
${ }^{12} \mathrm{Ibid}, \mathrm{hlm} ., 258$
}

13 Ibid. 


\section{Latief Mahmud}

kematangan seksualnya terlalu dini sedang orang dewasa adanya kelambatan seksual atau adanya gangguan neorotis dari perkembangan emosionalnya.

Gejala abnormal seksual lainnya yaitu seseorang baru mendapatkan kepuasan seksual bila partner seksualnya disakiti seperti menampar, memukul, menggigit, mencekik atau menggosokgosokan benda tajam disikitar wajah, perut dan payu dara partnernya, perilaku ini disebut dengan istilah sadisme dan sebaliknya suatu kepuasan seksual dapat diraih bila menyakiti diri sendiri atau disakiti, perilaku ini disebut maschism. Bisanya kepuasan seksual seperti ini banyak dianut oleh kaum homoseksual, karena mereka rela tersiksa untuk mendapatkan cinta dan kasih sayang dari pasangan seksualnya, hal ini paling banyak dialami kaum wanita.

\section{Penyimpangan seksual dengan cara homoseksual}

Homoseksualitas merupakan penyimpangan seksual disebabkan partner seksnya tidak normal. Sebelum berbicara mengenai masalah homoseksual terlebih dahulu perlu dijelaskan tentang pengertian seks itu sendiri. Sebab pembahasan ini menyinggung masalah psikologi seksual dengan permasalahan kelainan seksual. Menurut para psikologi bahwa; seks itu adalah suatu mekanisme bagi manusia agar mampu mengadakan keturunan, sebab itu seks merupakan mekanisme yang vital dimana manusia mengabadikan jenisnya ${ }^{14}$

Di samping hubungan sosial yang biasa di antara laki-laki dan perempuan bisa juga terjadi hubungan khusus yang sifatnya erotis yang bisa disebut dengan istilah relasi seksual. Dengan relasi seksual ini kedua belah pihak menghayati bentuk kenikamatan atau puncak kepuasan yang bisa disebut dengan istilah orgasme bila dilakukan dalam hubungan yang normal. Hubungan seksual yang normal itu adalah hubungan di antara dua jenis kelamin yang berlainan antara pria dengan wanita disebut sebagai relasi heteroseksual. Tetapi jika dilakukan dua jenis kelamin yang sama maka perbuatan ini dianggap tidak normal dan itu disebut homoseksual.

14 Ibid, hal. 225 
Menurut para pemerhati psikologi-seksual bahwa jumlah pria homoseksual lebih banyak 3-4 kali dari pada wanita homoseksual15. Ekspresi kaum homoseksual ada tiga macam yaitu aktif, pasif dan bergantian peranan. Homoseksual yang berperan aktif bertindak sebagai pria yang agresif, yang berperan pasif sebagai wanita dan peranan yang bergantian yaitu kadang-kadang berperan sebagai pria dan kadang-kadang berperan sebagai wanita.

Ada beberapa teori yang mengatakan bahwa sebab-musabab terjadinya homoseksual itu antara lain; (a) faktor herediter yaitu ketidak seimbangan hormon-hormon seks, (b) pengaruh lingkungan yang tidak baik yang tidak menguntungan bagi perkembangan kematangan seksual yang normal, (c) pernah mengalami homoseksual pada masa remaja, (d) tinggal di asrama atau penjara khusus untuk pria atau khusus untuk wanita ${ }^{16}$.

Homoseksualitas pada pria yang disebut gay itu berlangsung dengan cara memasukan zakar atau kelaminnya kedalam mulut partnernya dengan menggunakan lidah dan bibir untuk menggelitik atau dengan memasukan zakarnya kedalam anus atau dubur lawan seksualnya sebagai cara untuk bersenggama yang biasa disebut sebagai anal seks atau sodomi.

Homoseksual dari kaum wanita disebut lesbianism, pada usia remaja muncul pembawaan atau kecenderungan mencintai sesama putri sekaligus mencintai seorang pria yang biasa disebut dengan istilah biseksual. Dalam proses perkembangan remaja putri yang normal biseksualitas remaja akan berkembang menjadi hetroseksualitas yang menandai dirinya sebagai wanita tulen. Tetapi jika proses perkembangan itu abnormal disebabkan faktor-faktor tersebut diatas kemungkinan akan menjadi seorang lesbianism.

Menurut pengamatan bahwa cinta homoseksualitas wanita itu (lesbianism) lebih mendalam dari pada cinta hetroseksual maupun cinta dari pada kaum gay, walaupun relasi seksual lesbian itu tidak bisa terpuaskan secara wajar. Sebab-sebab terjadinya lesbianism adalah perversi (pembelotan) dari seorang hetroseksual itu menjadi

\footnotetext{
${ }^{15}$ Ibid. hal. 248

16 Ibid.
} 


\section{Latief Mahmud}

seorang lesbianism karena jenuh dalam relasi seksualnya dengan suaminya atau karena tidak pernah merasakan kepuasan seksual (orgasme) dengan suaminya, atau karena truma dengan suaminya yang kejam dan sadis sehingga timbul kebencian terhadap kaum lakilaki lalu lebih suka melakukan relasi seksual dan hidup bercinta dengan seorang wanita lain sebagai kompensasi dari rasa tidak bahagia.

Manifestasi lesbianism itu ialah kedua partner tersebut secara bergantian memainkan peranan sebagai laki-laki dan peranan wanita. Biasanya yang berperan sebagai pria bersikap sebagai maskulin, aktif dan sadis sedang partnernya berperang sebagai wanita bersikap pasif feminin. Sedang pemuasan seksual pada lesbian biasanya dengan cara oral-seks yaitu melalui mulut dengan kelaminnya. Atau dengan memakai sabuk yang berpenis seperti kelamin laki-laki. Kedua partner ini biasanya melakukan relasi seksual secara bergantian memegang peranan sebagai laki-laki

\section{Homoseksual: Perspektif Hukum Islam}

\section{Hukum Homoseksual dalam Perspektif Al-Qur'ân}

Tak ada keraguan dalam Islam bahwa perilaku homoseseksual dianggap sebagai perbuatan terlarang dan diharamkan serta berdosa besar bagi orang melakukannya. Manusia secara alamiayah tidak ada yang homoseks, manusia bisa menjadi homoseks karena lingkungannya dimasa pubernya, namun begitu lingkungan tidak bisa dijadikan pembenaran terjadinya homoseksual karena manusia memiliki akal fikiran yang bisa memilih dan seksualitas itu adalah pilihan. Manusia mengendalikan pikiranpikiran itu dan mengambil keputusan. Namun pilihan itu harus disadari dan dimengerti keberadaannya karena kalau tidak ia akan terjebak dalam pemikiran yang sesat menerima hipotesis dari diri kita sendiri sebagai kebenaran bukan sebagai pilihan yang mungkin.

Salah satu tujuan dari seksualitas alamiyah yaitu reproduksi. Hubungan seksual yang alamiyah dan sah antara pria dan wanita telah dirancang oleh Allâh swt untuk melayani kebutuhan umat manusia di muka bumi. Homoseksual bertentangan dengan peran dan tujuan sunnatullah dari aktivitas seksual. Islam tidak menerima 
apapun pembenaran bagi homoseksual walaupun ada faktor-faktor biologis ataupun lingkungan mempengaruhi seseorang dan dapat mendorong untuk melakukan perbuatan-perbuatan tertentu termasuk perbuatan menyimpang. Pengaruh destruktif (merusak) yang membuat seseorang memiliki perilaku hewani, amoral tidak bisa dijadikan pembenaran atas tindakannya, karena manusia memiliki kemampuan dalam mengendalikan pikirannya dan memiliki kehendak bebas. ${ }^{17}$

Manusia harus mampu mengendalikan dirinya, mengendalikan hasrat seksualnya, ia harus melatih dirinya menahan emosi dan tuntutan biologis yang bertentangan dengan hukum. Manusia adalah makhluk ciptaan Allâh yang paling sempurna, paling tinggi derajatnya. Manusia memiliki kewajiban moral untuk mengendalikan nafsunya dan ia dianugerahi akal fikiran dan kehendak bebas untuk dapat melakukan sesuatu yang bermanfaat. Hewan dianugerahi nafsu tapi tidak dianugerahi akal, Malaikat dianugerahi akal tapi tidak dianugerahi nafsu, sedang manusia dianugerhi keduanya yaitu nafsu dan akal, maka siapa yang dapat mengatasi nafsunya dengan akalnya maka ia lebih mulia dari pada malaikat dan siapa yang nafsunya mengalahkan akalnya maka ia hina dan rendah dari pada binatang.

Tidak ada tempat dalam Islam bagi perilaku homoseksual. Ia adalah perbuatan terlaknat dan perbuatan dosa seperti difirmankan Allâh swt dalam Al-Qur'ân sebagai berikut ;

ولوطا اذ قال لقومه اتأتون الفاحشة ماسبقكم بها من احد من العالمين انكم لتأتون الرجال

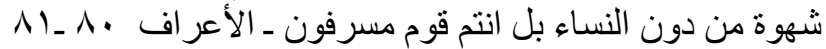

Artinya :

"Dan (Kami juga telah mengutus) Lûth (kepada kaumnya), ingatlah tatkala ia berkata kepada kaumnya "mengapa kalian mengerjakan perbuatan keji ini yang belum pernah dikerjakan oleh seorangpun (di dunia ini) sebelum kalian. Sesungguhnya kalian mendatangi laki-laki untuk memuaskan nafsu kalian

\footnotetext{
17 Ibid. hlm.35
} 


\section{Latief Mahmud}

bukan kepada wanita, kalian adalah kaum yang melampaui batas (surat al-A'raf 80-81) 18

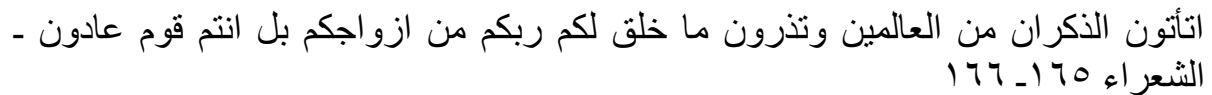

Mengapa kalian mendatangi jenis laki-laki di antara manusia dan kalian tinggalkan istri-istri yang dijadikan oleh Tuhan untukmu, kalian adalah orang yang melampau batas (surat alSyu'arâ' 165-166) ${ }^{19}$

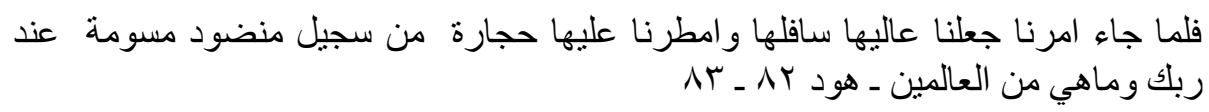

Maka tatkala datang azab kami, kami jadikan negeri kaum Luth itu longsor dan kami hujani mereka dengan batu dan tanah yang terbakar dan siksaan itu tiada jauh dari orang yang berbuta, dhalim (surat Hîd 82-83)20

Dari beberapa ayat di atas dapat diraik kesimpulan bahwa Allâh melarang segala hubungan seks selain hubungan seks yang diikat dengan hubungan perkawinan antara seorang laki-laki dengan seorang perempuan.

Menurut Mohammad Rashfi seperti dikutip oleh Sayid Sâbiq, pelarangan homoseksual disebabkan dampaknya yang negatif terhadap kehidupan pribadi dan masyarakat, di antaranya adalah pertama, tidak tertarik pada wanita, akan tetapi tertarik pada sesama jenisnya; kedua, menyebakan gangguan otak; dan ketiga, tersebarnya virus AIDS. ${ }^{21}$

\section{Hukuman Pelaku Homoseksual Perspektif Ahli Fiqh.}

Para ahli Fiqh sekalipun sepakat terhadap keharaman perilaku homoseks, akan tetapi mereka berbeda pendapat dalam hal hukuman bagi pelaku homoseksual. Pertama, Imâm al-Syâfi'î berpendapat

18 Departemen Agama RI., Al-Qur'an dan Terjemahan (Jakarta: PT. Bumi Restu, 1979), hlm. 234.

19 Ibid., 354.

${ }^{20}$ Ibid., hlm., 585.

${ }^{21}$ Sayid Sâbiq, Fiqh As-Sunnah, juz, I (Libanon; Dâr al-Fkr, 1981), hlm. 361-365. 
bahwa pelaku homoseks dihukum dengan hukuman mati. Pendapat ini didasarkan pada hadis yang diriwayatkan oleh Ibn Abbâs :

$$
\text { من و جد تموه يعمل عمل قو ملو ط فا قتلوا الفا عل و المفعو ل به }
$$

Dengan dasar hadis itulah, maka hukuman bagi pelaku homoseksual adalah hukum mati.

Kedua, Abû Yûsuf dan Imâm Auzâ'î menyatakan bahwa hukuman bagi pelaku homoseks disamakan dengan hukuman bagi pezina, yaitu hukuman dera dan diasingkan bagi yang belum kawin serta rajam bagi yang sudah kawin. Pendapat ini secara metodologis menggunakan metode Qiyâs yang mempunyai kesamaan illat yaitu penyaluran syahwat tidak pada jalan yang dibenarkan dan disyahkan oleh syara'

Ketiga, pendapat dinyatakan oleh Imâm Abû Hanifah. Menurut beliau hukuman bagi pelaku homoseks berlaku hukum $t a^{\prime} z \hat{\imath} r$, yang jenisnya menjadi wewenang hakim. Pendapat ini didasarkan pada pendapat bahwa hukuman ta'zîr itu dijatuhkan terhadap kejahatan yang tidak ditentukan macan dan kadarnya dalam al-Qur'ân. ${ }^{22}$.

\section{Penutup}

Perilaku homoseksual adalah perbuatan bodoh, buruk yang menimbulkan kerusakan, bertentangan norma-norma alamiyah, norma-norma sosial dan etika, dan menghambat pertumbuhan dan penyebaran kehidupan umat manusia serta banyak menyebabkan penyakit menular seperti Aids, penyakit kelamin, kencing nanah, sifilis (raja singa), herpes kelamin, hepatitis B, kanker dubur, kanker getah bening, kanker jaringan pembuluh darah dan penyakit mental.

Al-Qur'ân dan hadîts Nabi memandang bahwa perilaku homoseksual itu adalah menyerupai perilaku yang dilakukan oleh kaumnya Nabi Lûth, karena itu perlu dilaknat dan harus dijauhi. Akan tetapi walaupun para ahli fiqh sepakat akan keharamannya, masing-masing di antara meraka menetapkan hukuman dengan hukuman yang berbeda. Al-Syâfi'î menyatakan agar mereka dihukum

\footnotetext{
22 Abdul Qadir Audah, at-Tasyrî' al-Jinâ'î al-Islâmî̀; Muqâran bi al-Qanûn al-Wath'î, juz I
} (Iskandaria: Dâr Nasyr at-Tsaqafîyah, 1949), hlm. 185-186. 
mati, Abû Yûsuf dan Imâm Auzâ'î menyatakan bahwa hukuman bagi pelaku homoseks disamakan dengan hukuman bagi pezina, yaitu hukuman dera dan diasingkan bagi yang belum kawin serta rajam bagi yang sudah kawin, dan Imâm Abû Hanifah membelakukan hukum $t a^{\prime} z \hat{i} r$. 